\title{
Homenagem à professora Jane Piton Serra Sanches
}

A professora Jane Piton Serra Sanches, natural de Nova Aliança, interior de São Paulo, iniciou sua trajetória acadêmica em 1998, quando ingressou no Instituto de Biociências, Letras e Ciências Exatas - IBILCE, Universidade Estadual Paulista - UNESP, São José do Rio Preto para cursar Ciências Biológicas.

Começou a desenvolver estágio de nível básico ainda no primeiro ano do curso, com Biologia Vegetal dentro do Herbário da Instituição. Entretanto, quando teve contato com os peixes e com os conhecimentos da Sistemática Filogenética mudou de área, passando a desenvolver trabalhos com Sistemática e Taxonomia de Peixes de Água Doce Neotropicais, integrando a equipe do Laboratório de Ictiologia do IBILCE/UNESP.

Ainda durante a graduação foi membro do Programa de Educação Tutorial - PET - Biologia, desenvolvendo atividades de ensino, pesquisa, extensão e cultura, durante três anos de sua formação. Na graduação foi bolsista do PET - SISU/MEC e também de iniciação científica da FAPESP.

Ingressou no Mestrado em Biologia Animal do IBILCE/UNESP em 2002 e no doutorado no mesmo programa e Instituição no ano de 2006. Durante o doutorado atuou também como docente do IBILCE/UNESP, nos anos de 2008 e 2009, junto ao curso de Ciências Biológicas, ministrando as disciplinas "Invertebrados I", "Invertebrados II" e "Comportamento Animal".

Além das atividades de ensino, atuou em trabalhos de consultoria para várias empresas e órgãos públicos para elaboração de Planos de Manejo de Unidades de Conservação e Licenciamento Ambiental de empreendimentos.

Ingressou no IFSULDEMINAS em 2010, no Campus Muzambinho, onde permaneceu até 2011, atuando em vários cursos. Hoje é docente do Campus Poços de Caldas do mesmo Instituto, integrante da equipe de gestão desde 2012, ocupando o cargo de Diretora de Ensino, Pesquisa e Extensão.

Atualmente coordena o projeto de pesquisa "Levantamento da Ictiofauna do Planalto de Poços de Caldas", que visa determinar a composição de peixes da região peculiar do planalto de Poços, bem como determinar o estado de conservação dos corpos d'água da área. Além disso, integra a equipe de outros projetos desenvolvidos no campus e em outras instituições de ensino.

A profa. Jane é revisora da Revista Agrogeoambiental desde 2012, sendo atualmente Editora de Área do periódico.

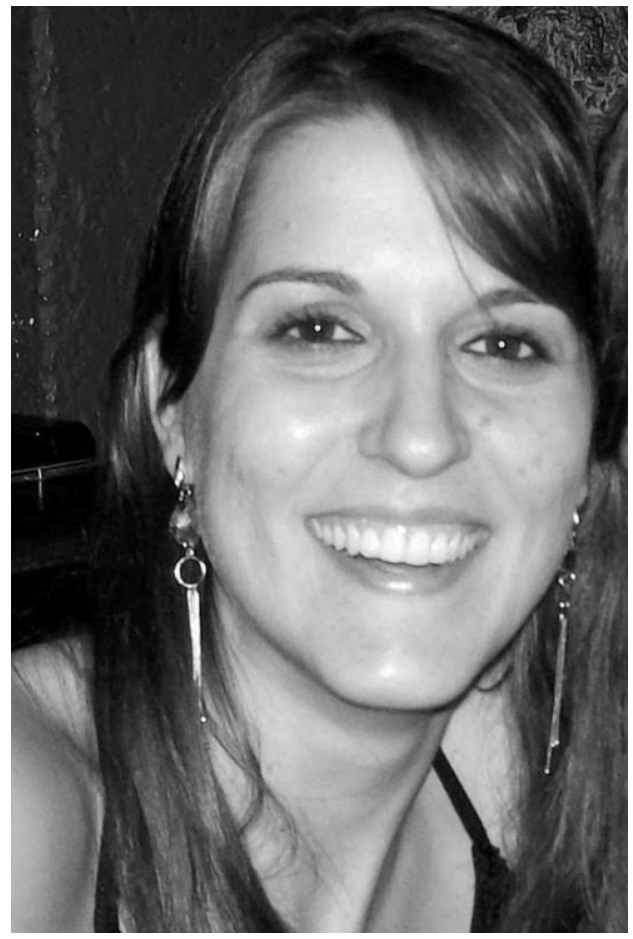




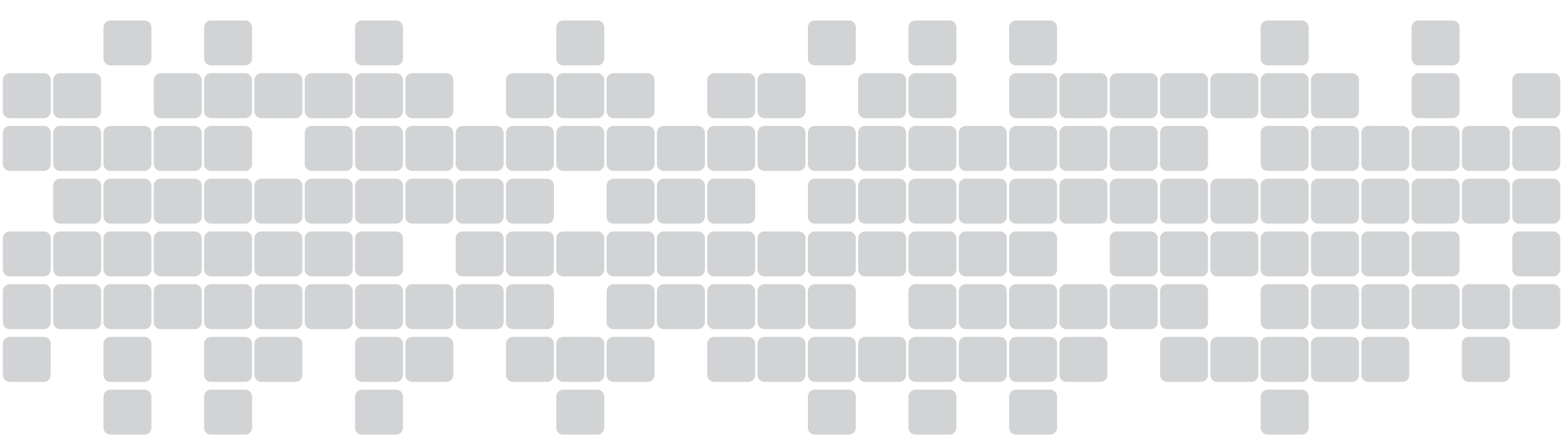

